\title{
THE VIRTUALIZATION OF HEALTH EDUCATION IN TIMES OF COVID-19
}

A VIRTUALIZAÇÃO DO ENSINO NA SAÚDE EM TEMPOS DE COVID-19

VIRTUALIZACIÓN DE LA EDUCACIÓN EN SALUD EN TIEMPOS DE COVID-19

\author{
NASCIMENTO, Karla Angélica Silva do 1 \\ NETO, Deodato Narciso de Oliveira Castro2 \\ TELLES, Julio Cesar Couto Bem Siqueira ${ }^{3}$
}

\begin{abstract}
The study aimed to understand the students' point of view regarding the virtualization of education in the master's degree program classes during COVID-19. This is a case study with a qualitative research approach, using an online questionnaire to identify, into the student's point of view, how virtualized teaching was applied in classes during social distancing. The results show that the use of these resources can significantly contribute to the learning process into the Health area, however, it is essential to invest on training to have a better use of the technologies, since it's not enough that the teacher have the tech resource if a qualified knowledge it's not transmitted to the student.
\end{abstract}

Keywords: Virtualization of education, Health Education, COVID-19, Online resources, Graduate Program.

\section{RESUMO}

O estudo teve como objetivo compreender a visão discente acerca da virtualização do ensino nas aulas de Mestrado em tempos de COVID-19. A investigação de abordagem qualitativa, do tipo estudo de caso, utilizou um questionário online para identificar, na visão do aluno, como a virtualização do ensino foi aplicada nas aulas durante o distanciamento social. Os resultados mostram que o uso desses recursos pode contribuir significativamente no processo de aprendizagem na área da Saúde, contudo, é fundamental investir na formação para melhor utilização dessas tecnologias, pois não adianta apenas o professor usar tais recursos tecnológicos se não há o conhecimento pelo aluno para uma ação qualificada.

Palavras-chave: Virtualização do ensino, Ensino na Saúde, COVID-19, Recursos online, Pós-Graduação.

\section{RESUMEN}

El estudio tuvo como objetivo comprender la visión de los estudiantes acerca de la virtualización de la enseñanza en las clases de Maestría en tiempo de COVID-19. La investigación fue realizada a través de un abordaje cualitativo, del tipo estudio de caso, Se utilizó un cuestionario online para identificar, según la visión del alumno, como la virtualización de la enseñanza fue aplicada en las clases durante el distanciamiento social. Los resultados muestran que el uso de esos recursos puede contribuir significativamente en el proceso de aprendizaje en el área de la Salud, y se identificó que es fundamental invertir en la formación para una mejor utilización de esas tecnologías, pues no es suficiente que el profesor use tales recursos tecnológicos si el conocimiento calificado no es transmitido para el alumno.

Palabras clave: Virtualización de la docencia, Docencia en Salud, COVID-19, Recursos en línea, Postgrado.

\footnotetext{
${ }^{1}$ Centro Universitário Christus - Unichristus - Fortaleza - Ceará - Brasil.

${ }^{2}$ Centro Universitário Christus - Unichristus - Fortaleza - Ceará - Brasil.

${ }^{3}$ Centro Universitário Christus - Unichristus - Fortaleza - Ceará - Brasil.
} 


\section{INTRODUCTION}

We are living a unique moment in digital and online technologies with the COVID-19 pandemic. Due to that situation, everyday practices within families, communities and workplaces have changed, and it is no different in education. With social distancing, in order to avoid contagion, all educational institutions in the world needed to virtualize their classes to continue the educational process, both in pedagogical and methodological practices and in management practices (UNESCO, 2020).

Given the circumstances, in Brazil the context is no different. The search for quick and efficient pedagogical practices became a challenge commensurate to the combat of COVID-19. Managers, teachers and students sought to adapt to virtual environments, to virtual reality, as well as to find and learn different digital resources to guarantee the habit of studying and the quality of education, even remotely. In addition, Brazilian regions have social and economic differences that can compromise virtual education due to quality internet access, which, in the case of the development of synchronous and asynchronous activities, partially impairs the educational process.

In this scenario, online platforms, mobile apps, video conferences and remote classes are presented as allies of the virtualization of education, enabling the continuance of educational services, without adversities for the students and with the possibility to fulfill the workload, since education cannot stop. Despite that, both teachers and students encountered that experience without any actual training to use those technologies and methodological strategies of remote teaching and learning.

With social distancing caused by the pandemic and the search for digital and online technological solutions to continue higher education, the following question arises: what do the students enrolled in the classroom-based modality of the stricto sensu Graduate Program in the Health field think about the virtualization of their classes? Thus, the objective of this research is to understand the students' point of view regarding the virtualization of education in classes of the Master's Program in times of COVID-19.

Therefore, this study is relevant because it discusses, from the students' point of view, how digital and online resources can benefit Health education through the virtualization of education in educational institutions, including stricto sensu Graduate Programs.

\section{RESEARCH METHODOLOGY}

This study has a qualitative approach and exploratory nature, since it doesn't anticipate systematic procedures in search of generalizations, but, instead, seeks a deeper understanding of a specific phenomenon, interpreting it and considering the singularities of the subjects' reality and their subjectivities (MINAYO, 2007). Thus, it is dedicated to research a single case, a private higher education institution (HEI), and, more specifically, a Graduate Program in the Health Education field, aiming to understand the students' point of view regarding the virtualization of education in the classes of the Master's Program in times of COVID-19. Therefore, this case study consists of an empirical 
investigation "[...] that investigates a contemporary phenomenon within its real-life context"4 (YIN, 2001, p. 32, our translation).

The choice of HEI considered the following aspects: 1) consent of the HEI with the approval of the research project; and 2) availability of digital and online resources to benefit the virtualization of education. Concerning the subjects who participated in the research, we considered all twenty students enrolled in the Master's Program at a private institution in Ceará, recommended by the $183^{\text {rd }}$ Meeting of the CTC-ES at CAPES and validated by the Ministry of Education (MEC, in Portuguese) through Decision MEC 654 from September 30th 2019 , as per publication in the Union's Official Gazette, on October $2^{\text {nd }}, 2019$, Section 1 , pages 744 to 749 . The Program aims to qualify human resources capable of providing andragogical, scientific and theoretical-conceptual information for Health Education, aiming to contribute to the development of educational activities and operation practices on the different levels of attention in Health. It is important to clarify that no students were excluded, since all students confirmed, in the initial contact through e-mail and a chat application, their availability to participate in the research about the virtualization of education in the Master's Program.

For data collection, we used an online questionnaire with seven questions, both multiple-choice and essay. This tool, according to Ramos (2013), is used for issues whose research objects correspond to issues of empirical nature, containing views, position, opinion and preferences of those researched.

Before applying the questionnaire, in the beginning of May 2020, we provided, via e-mail, the Free and Informed Consent Form, which presented the research objectives, the participation method, the lack of direct benefits, the ability to withdraw at any moment and the possible damages embarrassment, emotions etc. After the student's consent, we provided the link for the online questionnaire, executed on Google ${ }^{\circledR}$ documents. The data were collected within two weeks, with a total of twenty respondents. The answers were analyzed based on the Content Analysis technique (BARDIN, 2009).

During pre-analysis, we carried out the fluctuating reading and the organization of the most recurrent central themes, then we grouped the themes in categories according to the frequency in which they occurred, in order to later compress similar categories. This procedure resulted in four categories: I) experience with the virtualization of education; II) digital resources used in remote classes; III) challenges of remote collective activities; and IV) use of video conference in classes.

\section{RESEARCH RESULTS AND DISCUSSION}

Based on the plurality of ideas and conceptions, it was important to comprise the four categories that emerged from this research to shed light on a specific reality of stricto sensu Graduate Program in Health Education at a HEI in Ceará, since it is important to understand the educational circumstances affected by COVID-19 and the necessary conditions for students to use technologies to boost their own learning and with what pedagogical intent such strategies can become meaningful.

\footnotetext{
${ }^{4}$ Originally: "[...] que investiga um fenômeno contemporâneo dentro de seu contexto da vida real”. 


\section{a) Experience with the virtualization of education}

In the first category, we asked students to indicate if they experienced, at any point in their lives, the virtualization of classroom-based education or if they had participated in remote classes. Fourteen reported that they never had that opportunity and six stated that they used the workload available in blended modality (on-site and remote) in some disciplines in their undergraduate program, participating in remote activities through a virtual learning environment. We observed that even those who didn't have this experience had used some digital resource in remote classes of the course, such as: slide presentations, videos and Google Drive $§$ tools.

Nevertheless, all 20 students reported that they use other digital and online resources to develop some activity requested by the professor. Therefore, we infer that 11 indicated that they always seek to know new digital tools aimed at education in the Health field and that they are open to testing and learning. On the other hand, 9 students reported difficulties with the tools and wanted the professor to teach how to use them during remote classes.

Technologies in Health education have the potential to improve activities. However, to successfully use those technologies, students of that field need to be aware of the underlying social and theoretical concepts that influence their use, whether in educational activities that take place in the institution or in possibilities and practical limitations of their use (MASTERS, ELLAWAY, TOPPS, ARCHIBALD, HOGUE, 2016).

Among those researched, 10 students mentioned using some digital resources to accomplish activities; in addition, they reported feeling confident in integrating mobile technologies in different subjects discussed in the classroom. We highlight that the potential of integration between those technologies and other activities and materials, whose knowledge construction can happen collaboratively, enables, through the professor's attitude to make them available to students, multiple authorship and sharing resources outside the limits of the classroom (ROSCHELLE, DIMITRIADIS, HOPPE, 2013; BERRIBILI, MILL, 2018; BANFIELD, HADUNTZ, MAISURIA, 2018), which makes it relevant not only to use the technologies, but also to qualify how such resources are used.

We requested students to indicate if they had liked the experience of remote classes and the virtualization of education. All reported that they were able to adapt to the process and that they would like this resource to become permanent, even after the pandemic. We observed that, with the difficulties to implement a new study routine and understand methodological strategies presented in remote classes, students already used some digital resource in their classes, such as: slide presentations, videos and some Google Drive ${ }^{\circledR}$ tools. We believe that this experience with online tools was an aggregating element for that quick adaptation.

According to Nascimento and Castro-Filho (2016, p. 23-24, our translation), these technologies can provide support for learning with emphasis on mediated action. The authors suggest that there are three ways to frame that support: "a) students and teachers work collaboratively with mobile and 
individual technologies; b) the work can be done simultaneously; c) collaboration doesn't take place through the tool, but through the interaction between members of the group" 5 .

\section{b) Digital resources used in remote classes of the program}

In the second category, the use of technologies was analyzed. From there, we asked students about the tools used in classes and their involvement with web resources. All reported that they use social media and specific apps in personal and academic situations, after all, those technologies aren't restricted to the internal environments of the educational institution; virtual information can be integrated to the real environment, since learning with web-based activities enables different real scenarios.

Sharing information in the virtual learning environment and storage in the cloud were the most cited resources, with the claim that they help with time management, especially during the development of remote activities. The virtual environment used was Moodle ${ }^{\circledR}$ (Modular Object-Oriented Dynamic Learning Environment), which is characterized by a set of functionalities and has tools that represent material instructions that are usually created digitally and sent to the platform, such as: links for websites, insertion of files into office apps (slides, text editors, spreadsheets etc.), animations, video and audio files (ALVES, SIMÃO, LEITINHO, 2018). In addition, it also has resources for databases, tasks, chat rooms, forums, news, glossary, wikis, questionnaires. These resources provide creation, organization and submission of activities, communication, collaboration, sharing and evaluation.

Although all graduate students acknowledged that these technologies weren't created exclusively for education, they agree that their integration in remote classes during social distancing offers a group of fruitful opportunities, that they can understand the content in different ways, be it through videos, simulators, animations, learning objects and tools that encourage collaborative production. They also infer that, in the face of new and constant challenges presented by digital and online resources, it is necessary to understand that connectivity is a facilitating element of learning in different contexts.

This inference corroborates what was postulated by Park (2011), when we have a device handy that favors information in any space and time, mobility can present a range of physical and virtual paths. Santaella (2013, p. 15 , our translation) reinforces that this ease makes the student exchange learning experiences in an unprecedented way, since "[...] this fosters a type of communication which is ubiquitous, pervasive and, at the same time, embodied and multiply situated [...] in the individuals' movements in space and time"6.

All of these resources share mobility on different levels, with the ability to process digital data and media. In addition, we notice that the concept of mobility, both in history and in education, is not new (FANTIN, 2017; LAMAR, ROACH, 2019). With internet access, these devices evolved, amplified,

\footnotetext{
5 Originally: "a) os alunos e professores trabalham de forma colaborativa com tecnologias de uso móvel e individual; b) o trabalho pode ser feito de forma simultânea; c) a colaboração não é feita via ferramenta e sim por meio da interação entre os membros do grupo".

${ }^{6}$ Originally: "[...] isso disponibiliza um tipo de comunicação ubíqua, pervasiva e, ao mesmo tempo, corporificada e multiplamente situada [...] nos deslocamentos espaço-temporais dos indivíduos".
} 
perfected the means of communication and information between individuals. However, this use is still often personal or informal.

\section{c) Challenges of remote collective activities}

The third category attempted to identify the challenges of producing collaboratively in a remote modality. Based on the reports, the students were more interested in the practical activities that involved the use of a database, for example, using the bibliography manager for the publication of scientific articles, Endnote ${ }^{\circledR}$ (https://endnote.com/), which imports bibliographic references from the internet. Students admitted that they turn to technologies to make activities more organized, contributing to meaningful learning.

Concerning the challenge to accomplish collaborative activities, students reported that the internet has and offers more advantages than disadvantages, since it enables the formation of a ubiquitous individual, because computer services and conveniences used in different location situations transmit a feeling of omnipresence that can facilitate the process of collaborative production. In addition, this activity can be carried out at any time and in different places.

The main resource used by the 20 students in collective tasks were Google Drive ${ }^{\circledR}$ tools (slide presentations and text documents). These technologies were used in order to enable the interaction among the group for the dissemination and discussion of knowledge.

According to Valente, Almeida and Geraldini (2017), Bierhalz, Felcher and Dias (2017), the challenges of using resources are related to the pedagogical strategies applied to develop activities involving mobile technologies in class. With that, the authors reveal that the student doesn't have to be an expert on computer systems or know all the functionalities of a digital resource, the key is for them to recognize their role within a social reality in constant change and, thus, be open to the new, seeking to use that technology in their learning process.

Although relatively familiarized with some technological resources, 5 students pointed to specific difficulties in the adaptation to the virtual learning environment or in the installation and execution of some apps. They emphasized that they are forced to handle unexpected situations, such as: the new version of the app or its new policy of access, which makes some functionalities stop being free and demand payment; the installation of programs and distribution of apps change in different operational systems - Windows $\AA$, Android $\AA$, Linux $\circledast$. That is, beyond being open to the new, seeking to use that

technology in their education, there are operational barriers that go beyond the necessity of technological understanding to the acquisition of specific knowledge (BOA SORTE, 2019; PRATALINHARES, ARRUDA, 2017).

\section{d) Use of video conference in classes}

Regarding video conferences, students discussed the importance of experiencing different resources to develop communicative abilities, such as: learning to listen, write and communicate remotely. They also brought up civility in discussions, such as: discussing subjects, presenting 
persuasive arguments, giving presentations and leading discussions, in a non-hostile manner. Thus, all students reported that video conferences were efficient in the development of communication.

The development of communication abilities and video conference etiquette is an important learning result intended for global learning disciplines, and data strongly support that capability as a result. Nascimento (2019), based on the results from several studies, emphasizes the importance of an environment that encourages the interaction between students to develop interdisciplinary competencies.

Meanwhile, 4 students reported that they prefer video conferences in the form of lectures and suggested the inclusion of some lectures in the course. One student suggested workshops to support the use of digital and online resources. In the beginning, the professors organized the classes through video conference with the same timetable as the in-person classes. However, the students themselves realized that the length of a video conference couldn't be the same as that of a class in a physical environment. Therefore, it was necessary to think of other tools, resulting in the establishment of a virtual learning environment and the development of asynchronous activities (TRIGUERO, 2018; CLAUDINO, 2013).

According to that point of view, experts at United Nations Educational, Scientific and Cultural Organization (UNESCO) throughout the world drafted a report with guidance for governments and sought to discuss the future of education during social distancing. UNESCO encourages policies for the use of mobile technologies during the school year. This may mean creating or updating existing policies regarding Information and Communication Technologies (ICT).

This process benefits course correction, since we expect effective and efficient pedagogical action. According to Lara (2016) and Torres (2017), listening to students about pedagogical strategies generates participation in society, and they can question the technologies, criticize them, analyze their contributions for social and political emancipation. Therefore, the curriculum comes to life, is rebuilt and resignified, and isn't restricted to the transference and application of determined content.

With that, students could be involved in a synchronous space linked to an asynchronous virtual learning environment and develop other class activities. We notice that, through reading and discussing scientific articles suggested in remote classes, students developed the abilities to better communicate during video conferences.

\section{CONCLUSION}

The objective of this study was to discuss students' understanding regarding the virtualization of education in the classes of a Master's Program in times of COVID-19. In order to contemplate that scope, we developed a qualitative study of the case study type, which used an online questionnaire as data collection tool and content analysis as a technique to compile and discuss the results.

From content analysis, four categories emerged: experience with the virtualization of education in classroom-based education; digital resources used in remote classes; challenges of remote collective activities; and use of video conference in classes. These results showed that the graduate students at the Master's Program indicated that they consider the virtualization of content and of classes relevant to 
mediate teaching and learning, especially because they enable a more dynamic class, contextualized with the student's reality and more meaningful, providing ubiquity and greater collective collaboration. However, they pointed to individual difficulties in using the technologies concerning, respectively, the fluctuation of the internet service and limited knowledge of specific technological resources, since they required time to search, learn and test constantly updated programs. The students already used digital technologies in their personal and academic life, but informally, because they acknowledged that those technologies enable updates and interactions between students and professors in any space and time, with social media, to share information and knowledge, as the most used tool.

The potential of the virtualization of education through integrating digital and online resources with other activities, materials and environments, whose knowledge production may happen collaboratively, occasions sharing knowledge during remote classes, amplifying teaching and learning. However, beyond the socialization of knowledge through sharing in social media, a practice already obtained by the students, it is important to use these technologies with aptitude, with their different resources and apps, in order to foster greater quality in the mediation of knowledge.

The students showed good level of knowledge about the use of synchronous and asynchronous tools (forum, sharing academic productions and video conference), which would probably help in the progress of virtualization of classes. Since technological advancement happens in an accelerated manner, the management of higher education courses in the Health field should promote strategies for the proper appropriation of these advancements in pedagogical practice. After all, students demonstrated that they are open and familiarized with new technologies.

Although this research, of qualitative nature, has its analysis lens reduced for attempting to understand the virtualization of classes to continue the process of teaching and learning at only one course of the Master's Program at one private HEI in Ceará, it is timely for allowing the visualization of the possibility to invest in the transformation of a specific reality. On a macro level, although it doesn't allow generalizations, since it is a case study, this investigation sheds light on everyday reflections regarding the virtualization of education during the pandemic and how it can contribute to the expansion of remote classes aiming to create a learning environment that is more interactive and conducive of meaningful education. Therefore, it is necessary to provide collective formative moments even remotely for actualization, a reality which extrapolates the need of a single institution and deserves debates and investment, including new studies investigating other realities.

\section{REFERENCES}

1. ALVES, F., SIMÃO, A. M., \& LEITINHO, M. Ação tutorial no ensino superior: experiência com alunos maiores de 23 em uma instituição pública de Portugal. Educação \& Formação, Fortaleza, v. 3, n.1, p. 44-65, 2018. ISSN: 2448-3583. Disponível em: https://revistas.uece.br/index.php/redufor/article/view/171 Acesso em: 26 ago. 2020. doi: https://doi.org/10.25053/redufor.v3i7.171 
2. ASSOCIAÇÃO NACIONAL PELA FORMAÇÃO DOS PROFISSIONAIS DA EDUCAÇÃO ANFOPE. Manifesto Contra a Medida Provisória n. 746/2016, 12 out. 2016. Disponível: <http://www.anfope.org.br/wp-content/uploads/2018/05/Manifesto-Anfope-MP-74612.10.2016R.pdf. Acesso em: 27 mar. 2019.

3. BANFIELD, G.; HADUNTZ, H.; MAISURIA, A. The (im)possibility of the intelectual worker inside the neoliberal university. Educação \& Formação, Fortaleza, v. 1, n. 3, p. 3-19, 2016. ISSN: 2448-3583. Disponível em: https://revistas.uece.br/index.php/redufor/article/view/110/93. Acesso em: 26 ago. 2020. doi: http://dx.doi.org/10.25053/edufor.v1i3.1974

4. BARDIN, L. Análise de Conteúdo. (4ª ed.). Lisboa: Edições, 70, 2009.

5. BERRIBILI, E., \& MILL, D. Impacto cognitivo do uso intensivo da internet: a autonomia dos estudos com dispositivos na adolescência. Educação \& Formação, Fortaleza, v. 3, n. 3, p. 177-188, 2018. ISSN: 2448-3583. Disponível em: https://revistas.uece.br/index.php/redufor/article/view/862 Acesso em: 26 ago. 2020. doi: https://doi.org/10.25053/redufor.v3i9.862.

6. BIERHALZ, C. D., FELCHER, C. D., \& DIAS, L. Os fóruns como estratégia didática para a construção do conhecimento. Educação \& Formação, Fortaleza, v. 2, n. 2, p. 75-94, 2017. ISSN: 2448-3583. Disponivel em: https://revistas.uece.br/index.php/redufor/article/view/137 Acesso em: 26 ago. 2020. doi: https://doi.org/10.25053/edufor.v2i5.1957

7. BOA SORTE, P. Internet memes: classroom perspectives in the context of digital cultures. Educação \& Formação, Fortaleza, v. 4, n. 3, p. 51-66, 2019. ISSN: 2448-3583. Disponível em: https://revistas.uece.br/index.php/redufor/article/view/1385 Acesso em: 26 ago. 2020. doi: https://doi.org/10.25053/redufor.v4i12.1385

8. CLAUDINO, Osmundo Rocha. Educar na sociedade da informação. Reflexão e Ação, Santa Cruz do Sul, v. 21, n. 2, p. 19-72, 2013. ISSN: 1982-9949. Disponível em: https://online.unisc.br/seer/index.php/reflex/article/view/3437 Acesso em: 26 ago. 2020. doi: http://dx.doi.org/10.17058/rea.v21i2.3437

9. FANTIN, M. Educação, aprendizagem e tecnologia na pesquisa-formação. Educação \& Formação, Fortaleza, v. 2, n. 3, p. 87-100, 2017. ISSN: 2448-3583. Disponível em: https://revistas.uece.br/index.php/redufor/article/view/161 Acesso em: 26 ago. 2020. doi: https://doi.org/10.25053/edufor.v2i6.2377

10. LAMAR, A. R., \& ROACH, E. F. La filosofia de la tecnología en la formación de ingenieros: algunas ideas sobre la experiencia de Cuba. Educação \& Formação, Fortaleza, v.4, n. 3, p. 3-20, 2019. 
ISSN: 2448-3583. Disponível em: https://revistas.uece.br/index.php/redufor/article/view/1425 Acesso em: 26 ago. 2020. doi: https://doi.org/10.25053/redufor.v4i12.1425

LARA, A. M. Políticas de redução da desigualdade sociocultural. Educação \& Formação, Fortaleza, v.1, n. $3, \quad$ p. 140-153, 2016. ISSN: 2448-3583. Disponível em: https://revistas.uece.br/index.php/redufor/article/view/118 Acesso em: 26 ago. 2020. doi: https://doi.org/10.25053/edufor.v1i3.1621

12. MASters, K., EllawAY, R. H., TOPPS, D., ARCHIBALD, D., \& HOGUE, R. J. Mobile technologies in medical education: AMEE Guide No. 105. Medical teacher, v. 38, n 6, p. 537-549, 2016. ISSN: 2448-3583. Disponível em: https://www.ncbi.nlm.nih.gov/pubmed/27010681. Acesso em: 26 ago. 2020. doi: 10.3109 / 0142159X.2016.1141190

13. MINAYO, M. C. S. O desafio do conhecimento. Pesquisa qualitativa em saúde. São Paulo: HUCITEC, 2007.

14. NASCIMENTO, K. A. S.; CASTRO FILHO, J. A. (2016). Dispositivos móveis na educação: ensinando e aprendendo em diferentes contextos. In: Anais Congresso Brasileiro de Informática na Educação, Minas Gerais, Uberlândia: SBIE, nov. 2016, p. 1225-1234.

15. NASCIMENTO, Karla A. S. Panorama das publicações científicas nacionais e internacionais sobre a aprendizagem móvel e a prática colaborativa. Educação \& Formação, Fortaleza, v. 4, n. 3, 2019, 207-229. ISSN: 2448-3583. Disponível em: https://revistas.uece.br/index.php/redufor/article/view/3342 Acesso em: 26 ago. 2020. doi: https://doi.org/10.25053/redufor.v4i12set/dez.3342.

16. PARK, Y. A pedagogical framework for mobile learning: Categorizing educational applications of mobile technologies into four types. International Review of Research in Open and Distributed Learning, v. 12, n. 2, p. 78-102, 2011. ISSN: 1492-3831. Disponível em: Acesso em: 26 ago. 2020. doi: https://doi.org/10.19173/irrodl.v12i2.791

17. PRATA-LINHARES, Martha Maria; ARRUDA, Rogério Dias. Inovação e integração das tecnologias digitais na docência universitária: conceitos e relações. Reflexão e Ação, Santa Cruz do Sul, v. 25, n. 2, p. 250-268, 2017. ISSN: 1982-9949. Disponível em: https://online.unisc.br/seer/index.php/reflex/article/view/8843 Acesso em: 26 ago. 2020. doi: http://dx.doi.org/10.17058/rea.v25i2.8843

18. RAMOS, Daniela Karine. Perfil dos alunos de Licenciatura a Distância e aspectos que contribuem para aprendizagem. Reflexão e Ação, Santa Cruz do Sul, v. 21, n. 2, p. 199-220, 2013. Disponível 
em: https://online.unisc.br/seer/index.php/reflex/article/view/2847 Acesso em: 26 ago. 2020. doi: http://dx.doi.org/10.17058/rea.v21i2.2847

19. ROSCHELLE, J.; DIMITRIADIS, Y.; HOPPE, U. Classroom orchestration: synthesis. Computers \& Education, [S.I.], 69, p. 523-526, 2013. ISSN: 0360-1315. Disponível em: https://www.sciencedirect.com/science/article/pii/S0360131513001036. Acesso em: 26 ago. 2020. doi: https://doi.org/10.1016/j.compedu.2013.04.010

SANTAELLA, L. Comunicação ubíqua: repercussões na cultura e na educação. São Paulo: Paulus, 2013.

21. TORRES, J. M. Exclusión social y educación superior: la respuesta pedagógica. Educação \& Formação, Fortaleza, v. 2, n. 3, p. 03-16, 2017. ISSN: 2448-3583. Disponível em: https://revistas.uece.br/index.php/redufor/article/view/157 Acesso em: 26 ago. 2020. doi: https://doi.org/10.25053/edufor.v2i6.2379

22. TRIGUERO, I. M. Gamificación y tecnologías como recursos y estrategias innovadores para la enseñanza y aprendizaje de la historia. Educação \& Formação, Fortaleza, v. 3, n. 2, p. 3-16, 2018. ISSN: 2448-3583. Disponível em: https://revistas.uece.br/index.php/redufor/article/view/267 Acesso em: 26 ago. 2020. doi: https://doi.org/10.25053/redufor.v3i8.267

23. VALENTE, J. A.; ALMEIDA, M. E. B.; Geraldini, A. F. S. Metodologias ativas: das concepções às práticas em distintos níveis de ensino. Revista Diálogo Educacional, Curitiba, v. 17, n. 52, p. 455478, 2017. ISSN: 1518-3483. Disponível em: https://www.redalyc.org/pdf/1891/189154955008.pdf. Acesso em: 26 ago. 2020. doi: http://dx.doi.org/10.7213/1981-416X.17.052.DS07

24. YIN, R. K. Estudo de caso: planejamento e método. Trad. Daniel Grassi. (2 ${ }^{\mathrm{a}}$ ed.). Porto Alegre: Bookman, 2001.

\section{Karla Angélica Silva do Nascimento}

Doutora em Educação Brasileira, Pós-Doutorado em Ensino na Saúde. Colaboradora do Programa de Pós-Graduação em Educação da Universidade Estadual do Ceará. Professora do curso de Mestrado Profissional em Ensino na Saúde e Tecnologias Educacionais - MESted do Centro Universitário Christus - Unichristus.

\section{Deodato Narciso de Oliveira Castro Neto}


Mestrando do curso de Mestrado Profissional em Ensino na Saúde e Tecnologias Educacionais MESted do Centro Universitário Christus - Unichristus. Graduado em Medicina pela Universidade Federal do Vale do São Francisco - UNIVASF.

\section{Julio César Couto Bem Siqueira Telles}

Mestrando do curso de Mestrado Profissional em Ensino na Saúde e Tecnologias Educacionais MESted do Centro Universitário Christus - Unichristus. Graduado em Medicina pela Faculdade de Medicina de Juazeiro do Norte - FMJ.

\section{Como citar este documento:}

NASCIMENTO, Karla Angélica Silva do; CASTRO NETO, Deodato Narciso de Oliveira; TELLES, Julio Cesar Couto Bem Siqueira. THE VIRTUALIZATION OF HEALTH EDUCATION IN TIMES OF COVID19. Reflexão e Ação, Santa Cruz do Sul, v. 29, n. 1, p. 08-19, jan. 2021. ISSN 1982-9949. Acesso em: doi: http://dx.doi.org/10.17058/rea.v29i1.15748 